CIHM

Microfiche

Series

(Monographs)
ICMH

Collection de microfiches (monographies)
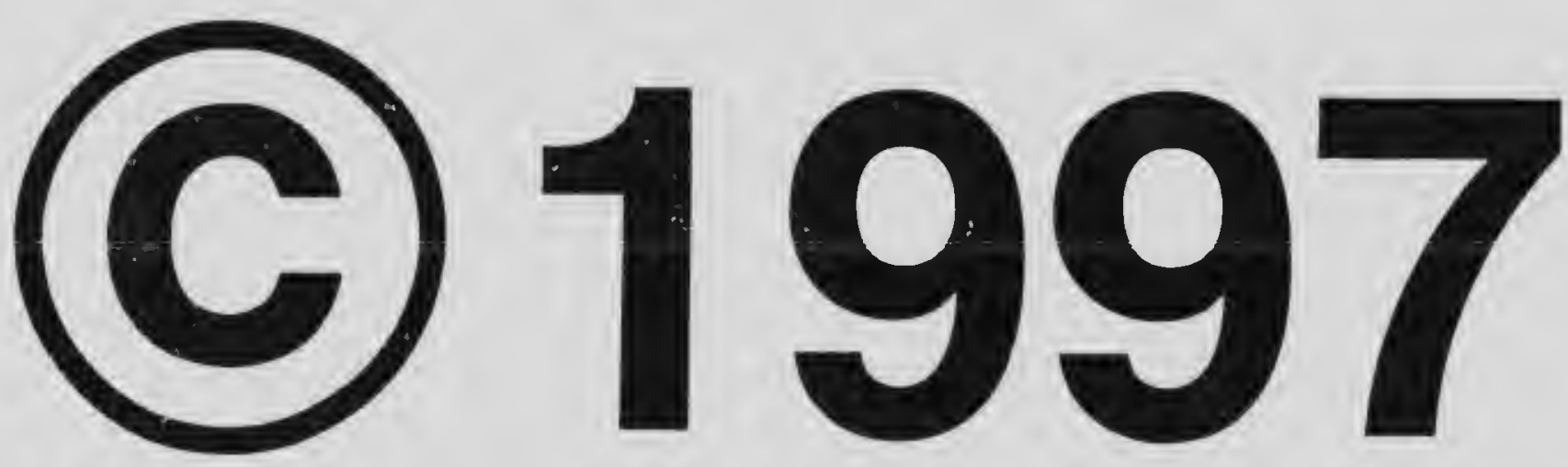


\section{Technical and Bibliographic Notes / Notes techniques et bibliographiques}

The Institute has attempted to obtain the best original copy available for filming. Features of this copy which may be bibliographically unique, which may alter any of the images in the reproduction, or which may significantly change the usual method of filming are checked below.

\section{Coloured covers /}

Couverture de couleur

\section{Covers damaged/}

Couverture endommagée

Covers r-stored and/or laminated /

Couverture restaurée et/ou pelliculèe

Cover title missing / Le titre de couverture manque

Coloured maps / Cartes géographiques en couleur

Coloured ink (i.e. other than blue or black) /

Encre de couleur (i.e. autre que bleue ou noire)

Coloured plates and/or illustrations /

Planches et/ou illustrations en cou'eur

Bound with other material /

Relié avec d'autres documents

Only edition available /

Seule édition disponible

Tight binding may cause shadows or distortion along inteior margin / La reliure serrée peut causer de l'ombre ou de la distorsion le long de la marge intérieure.

Blank leaves added during restorations may appear within the text. Whenever possible, these have been omitted from filming / II se peut que certaines pages blanches ajoutées lors d'une restauration apparaissent dans le texte, mais, loısque cela était possible, ces pages n'ont pas été filmées.

Additional comments /

Commentaires supplémentaires:
L'Institut a microfilmé le meilleur exemplaire qu'il lui a été possible de se procurer. Les détails de cet exem. plaire qui sont peut-être uniques du point de vue bibliographique, qui peuvent modifier une image reproduite, ou qui peuvent exiger une modification dans la méthode normale de filmage sont indiqués ci-dessous.

\section{Coloured pages / Pages de couleur}

Pages damaged / Pages endommagées

Pages restored and/or laminated /

Pages restaurées et/ou pelliculées

Pages discoloured, stained or foxed /

Pages décolorées, tachetées ou piquées

Pages detached / Pages détachées

Showthrough / Transparence

Quality of print varies /

Qualité inégale de l'impression

Includes supplementary material /

Comprend du matériel supplémentaire

Pages wholly or partially obscured by errata slips, tissues, etc., have been refilmed to ensure the best possible image / Les pages totalement ou partiellement obscurcies par un feuillet d'errata, une pelure, etc., ont été filmées à nouveau de façon à obtenir la meilleure image possible.

Opposing pages with varying colouration or discolourations are filmed twice to ensure the best possible image / Les pages s'opposant ayant des colorations variables ou des décolorations sont filmées deux fois afin d'obtenir la meilleure image. possible.

This item is filmed at the reduction ratio checked below /

Ce document est lilmé au taux de réduction indiqué cì-dessous.

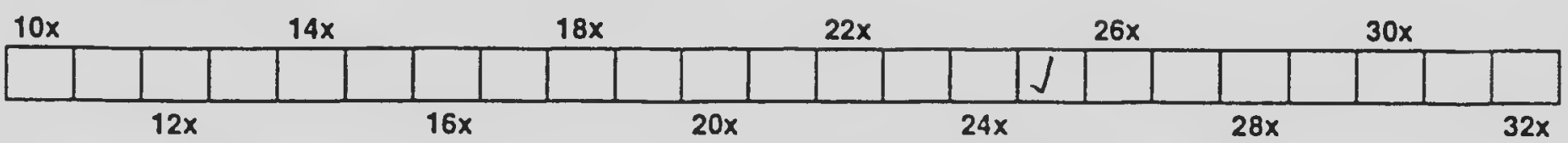


The copy filmed here has been reproduced thanks to the generosity of:

\section{Library \\ Agriculture Canada}

The images appearing here are the best quality possible considering the condition and legibility of the original copy and in keeping with the filming contract specifications.

Original copies in printed paper covers are filmed beginning with the front cover and ending on the last page with a printed or illustrated impres. sion, or the back cover when appropriate. All other original copies are filmed beginning on $t$,e first page with a printed or illustrated impres. sion, and ending on the last page with a printed or illustrated impression.

The last recorded frame on each microfiche shall contain the symbol $\rightarrow$ Imeaning "CON. TINUED"), or the symbol $\nabla$ (meaning "END"), whichever applies.

Maps, plates, charts, etc., may be filmed at different reduction ratios. Those too large to be entirely included in one exposure are filmed beginning in the upper left hand corner, left to right and top to bottom, as many frames as required. The following diagrams illustrate the method:
L'exemplaire filmé fut reproduit gráce à la générosité de:

\section{Bibliothèque \\ Agriculture Canada}

Les images suivantes ont été reproduites avec le plus grand soin, compte tenu de la condition et de la netteté de l'exemplaire filmb, et en conformité avec les conditions du contrat de filmage.

Les exemplaires originaux dont la couverture en papier est imprimb́e sont filmés en commençant par le premier plat et en terminant soit par la dernière page qui comporte une empreinte d'impression ou d'illustration, soit par le second plat, selon le cas. Tous les autres exemplaires originaux sont filmés en commençant par la premidre page qui comporte une empreinte d'impression ou d'illustration et en terminant par la dernière page qui comporte une telle empreinte.

Un des symboles suivants apparaîtra sur la derniere image de chaque microfiche, selon le cas: le symbole $\rightarrow$ slgnifie "A SUIVRE". le symbole $\nabla$ signifie "FIN".

Les cartes, planches, tableaux, etc., peuvent être filmés à des taux de réducticn différents.

Lorsque le document est trop grand pour etre reproduit en un seul cliché, il est filmé partir de l'angle supérieur gauche, de gauche a droite, et de haut en bas, en prenant le nombre d'images nécessaire. Les diagrammes suivants illustrent la méthode.
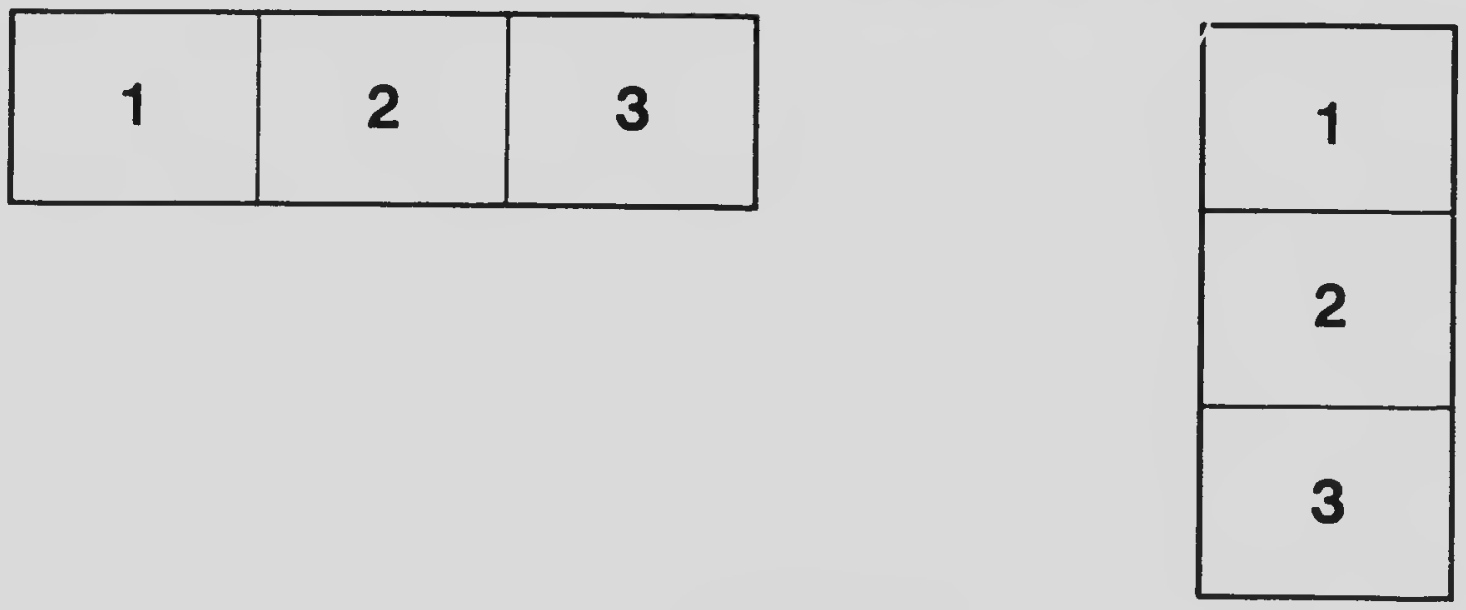

\begin{tabular}{|l|l|l|}
\hline 1 & 2 & 3 \\
\hline 4 & 5 & 6 \\
\hline
\end{tabular}




\section{MICROCOPY RESOLUTION TEST CHART}

ANSI and ISO TEST CHART No 2 ,
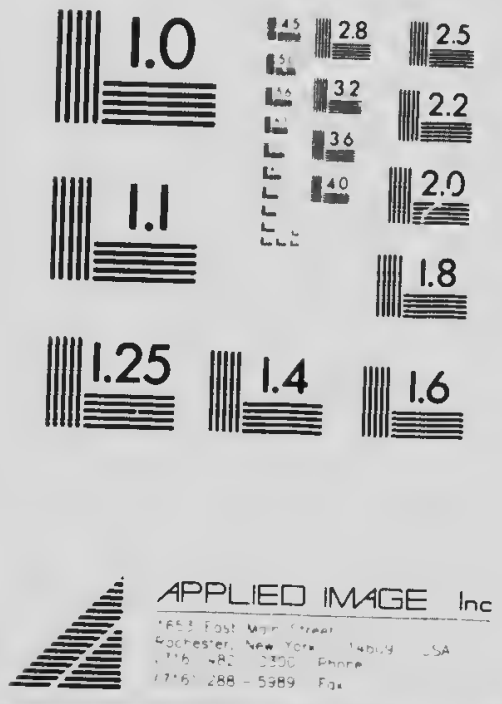


\title{
UNIVERSITY OF SASKATCHEWAN
}

\author{
FIELD HUSBANDRY CIRCULAR NO. 30
}

\section{Corn Growing in Saskatchewan}

\author{
BY L. E. KIRK AND J. B. HARRINGTON
}

COLLEGE OF AGRICULTURE, SASKATOON

\section{Corn Growing in Saskatchewan.}

The conditions which favour the growing of corn to its greatest priffection are high temperature and long growing seasons. Cool nights, and frosts in late spring and early fall therefore impose serious restrictions upon its use in northern latitudes. But while corn is a warm climate crop the continued selection of specially adapted early maturing types has resulted in the limits of successful corn-growing being pushed farther and farther northward. Corn has now a permanent place on the majority of farms in the northern states and it is growing in favour every year in the western provinces. While the season is not long enough to permit of profitable grain production, it has been demonstrated conclusively that corn can be grown successfully as a forage crop. As a substitute for fallow it will doubtless have a useful place in most of our wheat farming districts.

\section{The Four-Fold Value of the Corn Crop.}

Corn may be grown profitably in Saskatchewan as a forage crop, a cleaning crop, a substitute for fallow and as a means of lessening the cost of producing wheat. All four purposes are served at the same time.

Corn as a Forage Crop.-Under average conditions corn produces very fair returns. Yields of forage varying with the season and the culture given from 8 to 20 tons green weight per acre have heen reported from different parts of the province. In the least favourable season during the past five years at Saskatoon corn produced eight tons green weight per acre. In other years the yield has been as high as fourteen tons per acre. At Indian Head the average yield for some of the leading varieties for a period of five years is over seventeen tons of green weight per acre. Even when we allow for the large amount of water that green corn contains these yields compare very favourably with those of any other forage crop that we can grow. Ten tons of green corn cut when the cobs are partly formed is equivalent to about 2 tons of cured fodder.

Corn as a Cleaning Crop.-Weeds constitute the most serious hindrance to profitable grain farming in the older settled parts of the province and are already proving a menace in the newer sections. Continuous grain growing is impossible unless adequate means are found for keeping the land clean. Corn is one of the best crops for this purpose. The thorough culti- 
vation necessary for the successful production of corn aids materially in the control of weeds and thus offers another means for coping with a very difficult problem.

Corn as a Substitute for Fallow.-The summerfallow is admittedly an expensive method of controlling weeds and conserving moisture, in that a considerable part of the cultivated land is bringing in no returns. Besides the fallowed land provides the best possible conditions for soil drifting, which is becoming a serious drawback to profitable crop production in many places.

By substituting a corn crop for the summerfallow it is pcseible to make profitable use of the land every year. A crop of forage on land that would otherwise be idle is obviously a good thing, provided it can be hid without seriously reducing the yield of grain the following season. This is what actually occurs in practice if the corn land is kept clear of weeds. Wheat sown on corn ground frequently equals and sometimes exceeds the yield of the same crop when sown on fallowed land. The

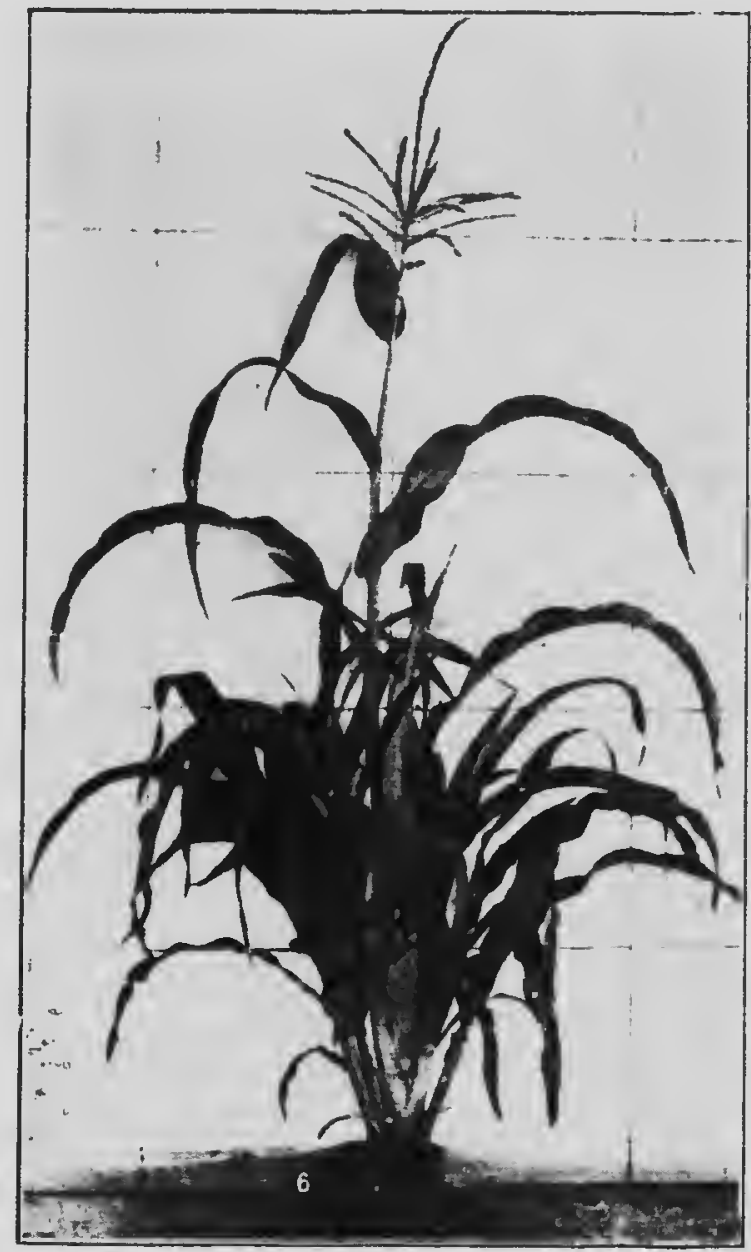

A Typical l'lant of an Farly flint Variety 
crop on corn ground also matures earlier than that on fallowed land. Experiments at Saskatoon have demonstrated that corn may replace summerfallow without materially affecting the yield of grain the next year. The sane result has been reported from the North Dakota Experiment Station, the Brancion and Indian Head Eixperimental furnis and from many farmers as well. In some yeurs the yields are slightly less but this is offset by an earlier and more evenly maturing crop.

In addition to doing the work of the fallow in controlling weeds and conserving moisture, corn will prevent soil drifting while the crop occupies the land, and the corn stubble, while not always preventing, will considerably lessen the drifting. And what is still more important, the manure resulting from the feeding of the corn crop will help replace the organic matter which is so essential to the control of both soil rrifting and soil moisture.

\section{Corn Lessens the Cost of Producing Grain.}

The cost of producing farm crops must be kept down if farming is to be profitable. Corn ground that has been well intertilled and kept clean does not need to be ploughed, hence the cost of a cereal crop is very considerably reduced and to that extent the profit on the succeeding crop is increased. A irop of fodder has also been obtained from the land the previous season without prejuclice to the grain crop that is to follow. These results, however, are not obtained unless the corn field is kept as clean as a good summertallow. Success depends on this factor more than on any other.

\section{Uses of the Corn Crop.}

In this province corn may be grown either for fodder, for soiling purposes, for "hogging off," or for silage. The form in which it is generally used at the present time is as cured fodder for cattle. For soiling purposes, however, dairy farmers will find it to be unexcelled for milk production in the dry part of the summer when the pastures have dried up. The "hogging off" of early maturing corn in the warmer parts of the province, while not yet practised to any extent, promises to aid materially in cheapening the cost of producing hogs as well as in lowering the cost of crop production.

Corn is the most suitable silage crop we have. In this connection it should be pointed out that a cheap form of silo, and on $t^{1}$ at in the western states is now being used quite exten. sively mely the pit silo, is likely to fill the early need of the lll stockman quite satisfactorily.

e early varieties of corn have ripened in the southern prarts of all three prairie provinces. A few men have selaiom failed to get seed sufficiently matured to grow. But as a grain crop, however much the future holds for us, at present it is not a commercial success except in local areas in the south and in favourable seasons elsewhere.

\section{Corn in the Rotation.}

What has been said of corn as a substitute for fallow indicates its natural place in the rotation. As a forage crop it can be used to most advantage by replacing as much of the summerfallow as seems practicable. In parts of Manitoba and eastern Saskatchewan, where the precipitation is sufficienl, corn might 
very well take the place of the fallow in such rotations as are used at present. For most of the prairie section of this province, however, the indications are that the wheat-oat-fallow rotation must be replaced in the near future by a more permanent system, including crops that will restore fibre to the soil. The following are suggested as suitable rotations of this type:

\section{Rotation No. 1}

1. Wheat.

2. Oats.

3. Corn.

1. Wheat (Secieded down to

5. Hay. grass).

6. Pasture.

7. Fallow.

Rotation No, 2 is a shortented form of No. 1, requiring less time to complete and fewer fields. It is recommended for the drier parts of the province where moisture consarvation is of most importance. Those who for any reason do not wish to depart from the wheat-oat-fallow plan would do well to plant corn on a tew acres of the fallow with a view to testing out its merits and getting tamiliar with the crop.

Fall or spring ploughed stubble makes a better seed bed for corn than fieshly broken sod and the land may be summertallowed after grass with practically no danger of soil drifting.

\section{Favourable Soil Conditions.}

Corn prefers a warm soil. Other conditions being similar it will start earlier and grow faster on a rich loam soil than on any heavier type. In our elimate, however, it has been commonly observed that, except in years of early fall frosts, corn priclices a much heavier growth of forage when planted on lcw lj.ig soil that is well supplied with moisture. A $11 \mathrm{ght}$, warm soil under similar condition would, no doubt, yield more. The ilup needs $b_{i} ! 1$ : $41 \mathrm{~m}$ and a noust soil. Wnele grain is desired warm soils arc essential, but where forage only is looked for, while warm soils are favoured, the crop will do well on all except the coldest types.

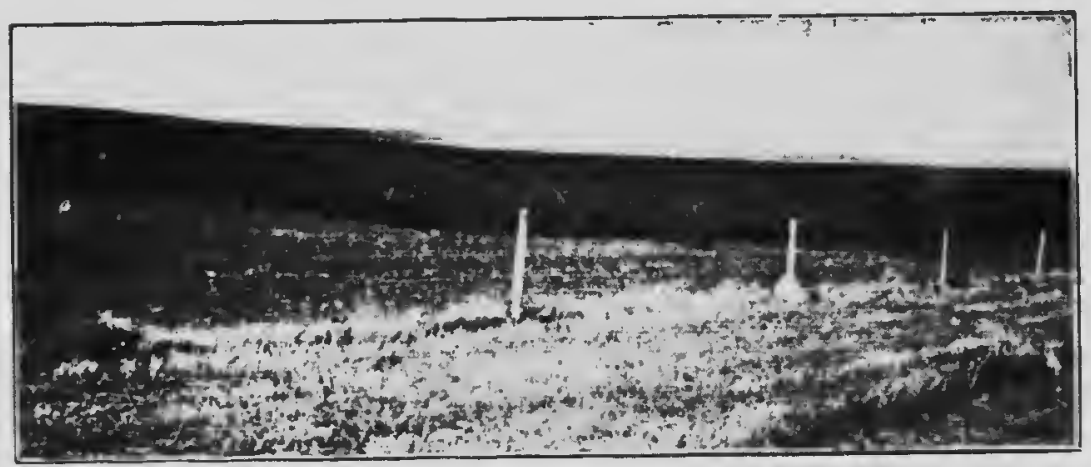

A Proftable Fleld of Cun Ruplaring Part of the Summerfallow. Gull Late. Sashatehewan. 1920. 


\section{Preparation of the Land.}

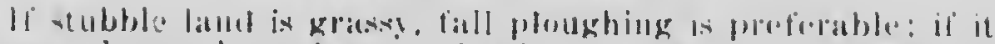
is cteall, thorollgh stlfole cultivation in the fall, followed by spring ploughimg. Woll worked down immorliately after the

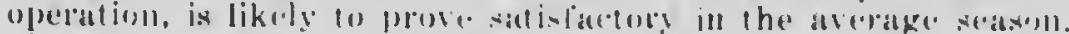

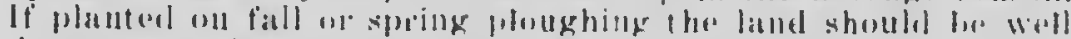

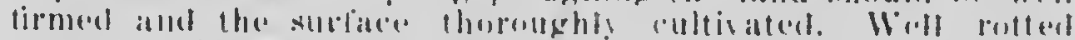

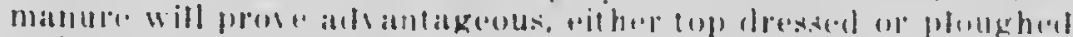
under. Sirally manure, if used, theuld be ploughed undere atnd

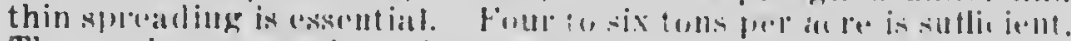

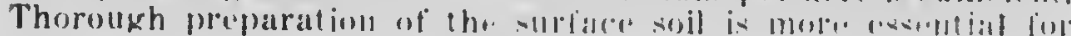

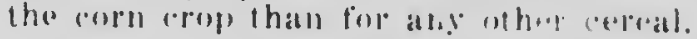

\section{The Choice of Varieties.}

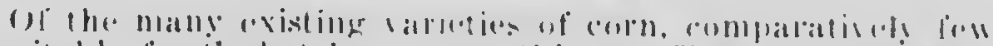
are suitable for Saskatchell all contlitons. The late dellts alll

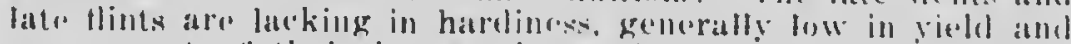
on acereunt of their immaturity at harve.et makr an inferior

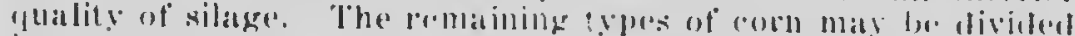

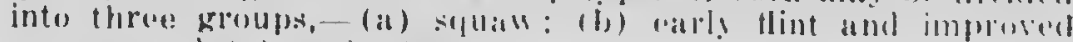
sifuill: and (1.) willy drollt.

Squaw Corn. The slllall larietics alle short alld relatively

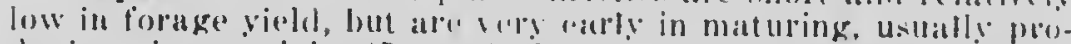

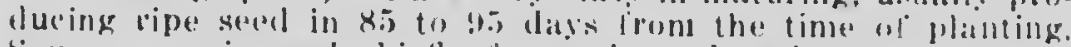

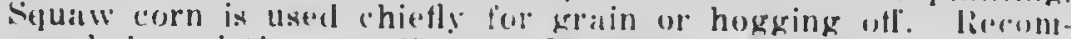
mended varieties an Squan. White Squaw and Assiniboinc Indian.

Early Flints.-The tarly tlint: of improved squatws atre taller, later and nuch heavier in rielel than the squatws. The 'ars mature in 100 to 120 dars. Varieties that have provel the must valuable in Saskatche Wan for forage or silage purpuses are Dakota White, Gehu, Quebec. No, 28 and Burleigh ('ounty Mixed.

Early Dents. - The early dlents are similar to the eally flints in height and yielel, but are late' in maturing. Northwestern Dent, which matures in $120101: 30$ days, is the most popular variety.

Results obtained at Sastatoon from tests made wer a periud of eight years are given in the accompanying table. The figures show that the early flints have produced a slightly higher arerage vield than the early dents. In favourable seasons with no frosts early in September the early clents gave the largest returns, but in seasons with coldl springs and early fall frosts the early flints were noticeably higher in vield.

Table Showing Yields of Corn at Saskatoon During the Period 1913 to 1920.

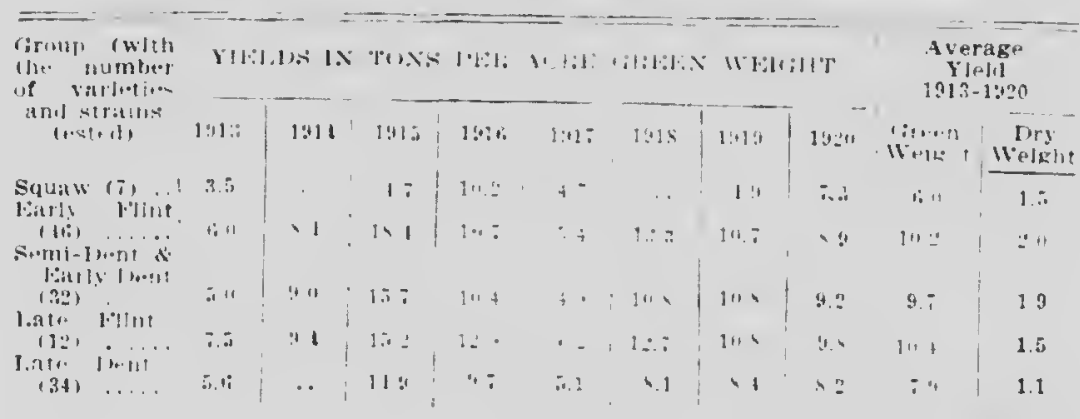




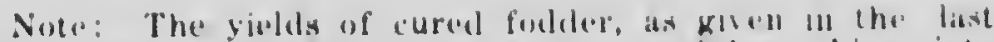
colunin, Were calculated trons the kreen weikhts taking into

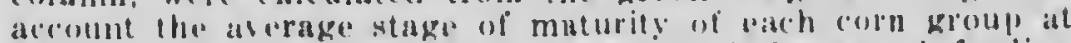
harvest tinc. This is u truer neasure uf the artual fordink vislao obtainod from all acre than the srocell "right.

\section{Testing the Seed.}

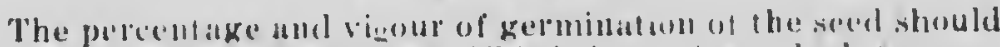
be leterminol bofore platting. This informattou, whloh for corn is nole important than for an:y other crop). ('all bo obtained caxily and quickly by cother flu blotting papere or the soil mothoul of

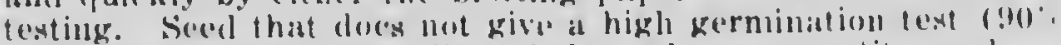
or over) slould either be discarled of a larger rfuatity used.

In this eomection it should be pointerl out that in all (o)tn

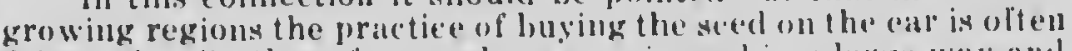
followed. (On those falnos where colll is llsod in at lage way and planted in hills it is advisable to purelase the seed on the ear.

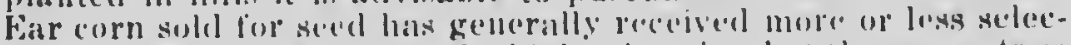

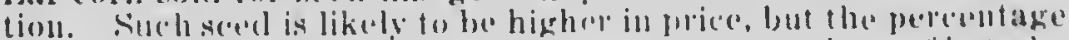

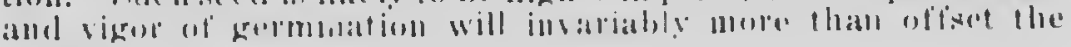
alditional ('o, tht.

\section{Planting the Crop}

Date of Planting.-The nrarrel corll can be lorought to matulity before fall frost the butler will be the quality of the

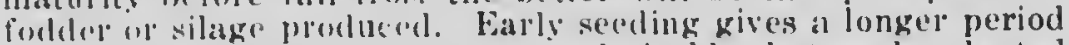
of growth and in that lospect is desirablo, but early planted corn frepuently docs not get along well owing to two causes:

1. If the soil is colrl part of the seed may rot and the re mainder germinate very slowly, causing a poor stand.

2. late splifin frosts often give early planted corn a severe setback.

In scasons froc of late spring frosts the May 10 seeding at Saskatuon produced more forage than any later planting. In 1915. When a severe frost came in June, the May 30 seeding wis the best. The largest average yiclds during an eight vear test Wre irom the May 20 and 30 plantings. Corn piasteci later thall this was lower in both yield and iuality. The usual practice is to sow luring the last $\because$ eek of May. In the southwestern poltion of the provine ine danger from frost is less and eorll may bo planted thers a week or two enrlier.

Method of Plantine.-Corn is planted either in rows with an ordinaly grain 1 ri: or in hills with a corn planter. In this country the most forage is usually secured from seeding in rows. Another alvantage of this method is that it does not reculuire the purchase ol a new inplement. Furthermore, it is the quickest way. To prepile a s'elel tor planting corn, block up six out of seven seed outlets, $0^{\cdot}$ better still, place a cardboard hopper or a large tin funnel over evely seventh opening in the drill box.

Where grain is the obiect sought, the hill method should he used, as corn, unlike wheat, matures most rapidly when riven plenty of room. Hill planting or checking is especially des rable on weedy land, for it gives opportunity for tillage in two directions-both lengthwise and acruss thr. rows. Checking corn 1.2. quires the wse of a hand planter or else the purchase of a corn planter. This outlay is partly offset by the saving in seed. 
Distance Apart of Rows. - Fixperimells cundlictud for eight

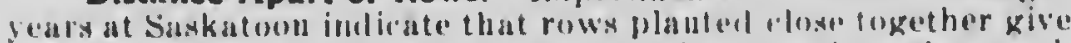
the larkest yielets but are the hixhest in the cost of weed control. The net prolit was greatest when the rows wore from : to id teet

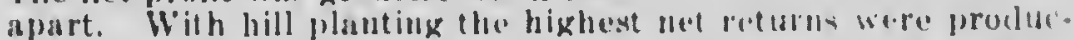

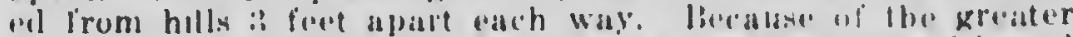

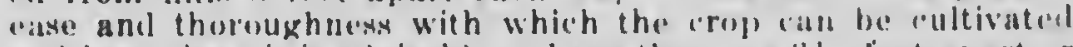
and kept clean it is alvisable en hase the rows 31 .2 lont apart or the hills 31 . lewt apart each way.

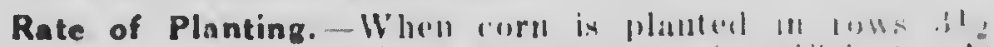
feet apart, about "20 pounds of socol per atero is stlticiont. At

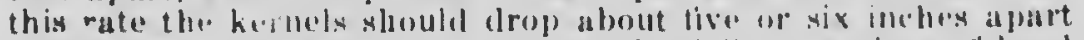

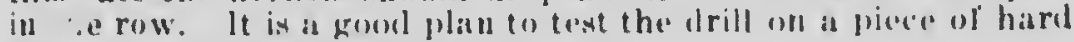

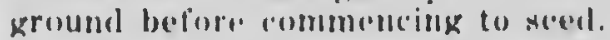

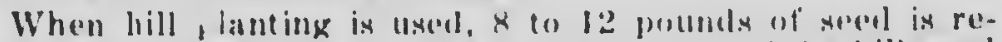

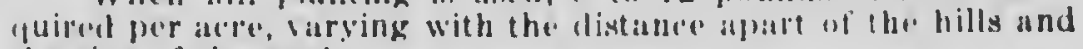
the size of the seed.

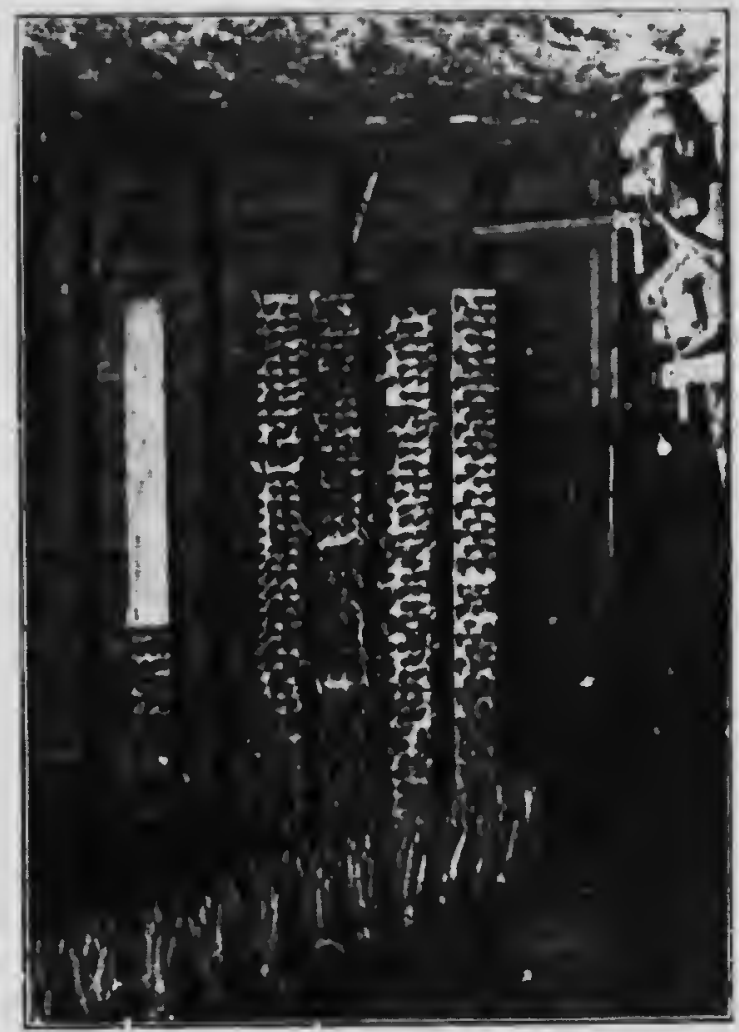

Drying Seed Corn In Saskatcliew:ın.

A Variely 'Test at Saskatoon in 1919. North-Westeril Wint at the left, Squaw in the two centre rows, and Dakuta White Flint at the riglit.

\section{Cultivation}

After corn is planted and until the crop is 6 inches high it may be harrowed with a light harrow. This practice is necessary in order to kill the thousands of small weeds that on most soils are sure to spring up. Harrowing once or twice before the 
corn is 6 inches high should be looked upon as a necessaly operatiol. If the harrowing is done on a warm, sunny day, the young corn plants being somewhat wilted, pass between the har row teeth without appreciable injury.

After the rop is high ellough that the rows are clearly distinguishable inteltillage should commence. The first cultivation may be fairly deep and close to the young plants, but later cultivation should be shallow. The more cultivation the "rop is given ul" to the time when it is impossible to get the horse or horses through between the rows the heavier the erop will be and the better comblition the land will be in for the following erop.

If small areas only ale planted to corn the one-pow cultivattor is guite sittistactory. For larger areas, however, a two-row matehine will quickly pay fol itself in the saving of one man's time.

\section{Harvesting}

The time io harvest the crop should be determined first. by the maturity of the arop, and, second, by the probability of fall fiosts. As a rule, in this country, the crop should be left as long as possible and ret aroid frosts. We have in the past usually cut our corn at Saskatoon in the first ten days of September. Occusionally frosts occur before this date, but sometimes they do not rome until considerably later. A slight frost usually stops the derelopment of the erop, without seriously injuring its feeding value. As a matter of fact, when corn is very green and inmature a slight frost results in drying it out to some extent, and thus makes the fodder easier to cure. It also makes green immature col'n less moist and the silage from it less sollr. In all cases where corn is taught by frost it should be cut as soon as possible. When frosted corn is left standing the plants rapidiy diy out and much of the feeding value is lost through weathering.

The havesting may be done with the sickle, the binder, or the eorm harvester. The first is the most laborious, and is advisable only when the crop is grown in a small way. The second plan is cuite satisfactory in most seasons. When corn is grown in large areas, and particularly if the crop is heavy, a corn harvester should be used.

A possible levelopment for corn lies in its use as a pasture crop for cattle in fall or early winter. This practice has not been extensively sturlied in Saskatchewan, but some men have reported favourably upon it. The difficulty and cost of the harresting which comes at a very busy time would be lessened, but whether the net return would be worth the effort has yet to be determined. By this method there is some danger of loss of stock due to forage poisoning or over-feeding.

\section{Curing and Storing}

Depending upon the uses to which it is to be put, the corll crop is cured in different ways. Tllat used for soiling purposes is, of course, cut green and fed in that condition. If it is to be used as roughage for stock it is cured by shocking it in the field.

Corn is sometimes left stooked in the field until needed and then drawn to the stable by the sleighload. A better method is 
to have it near the buildings in long ricks. These ricks should run east and west to allow the snow to be carried through by the prevailing winds and not banked up against the corn.

Fodder corn should not be stored in lofts or stacks unless layers of dry straw are placed between the layers of corn bundles. The layers of straw should be three or four times the thickness of the layers of corn, and the twine on the corn bundles should bn cut. The straw absorbs the moisture and prevents heating. This straw comes out of storage so flavoured by the corn that cattle eat it readily.

When stacked alone the corn should be well cured in the shocks, and the ricks or stacks must be made quite narrow to prevent spoiling. Some men have found that piling the cured bundles like cord wood is quite satisfactory.

The ideal way of storing fodder is in the silo. There are many types of silo, but all of the "above ground" types are rather expensive and at the present time can only be recommended for those having dairy farms or a considerable number of growing or fattening cattle. The "pit" or "underground silo" is much less expensive, and although less convenient, it promises to lend itself better to the conditions that exist on many western farms than does the more expensive "above ground" type.

\section{Equipment Necessary}

When corn is grown for fodder only, no equipment other than the grain drill, the one or two-horse cultivator and the grain binder is required at first. If after the crop has been tested thoroughly it is found to be satisfactory a horse drawn, two row planting machine, or a two-horse cultivator, or a corn harvester, or all three may be purchased. These machines save a great deal of time and may be used for other purposes as well as for handling the corn crop.

\section{Summary}

1. Corn is a warm climate crop growing slowly in cool seasons and is easily affected by frost.

2. The average yield of corn for the past eight years at Saskatoon is over 11 tons green weight (or over 2 tons dry weight) per acre. At Indian Head, corn yielded an average of 17 tons green weight per acre over a period of five years.

3 . Corn is our most satisfactory intertilled crop and offers a profitable means of controlling weeds.

4. Corn is a successful substitute for the summerfallow and when used as such materially aids is lessening soil drifting.

5. Corn lessens the cost of producing cereals.

6. Corn is used for winter fodder, silage, pasture, more particularly for hogs, and as a soiling crou.

7. Corn prefers a warm, moist, feitile soil.

8. A promising rotation for the drier parts of Saskatchewan consists of (1) wheat, (2) corn, (3) wheat or oats seeded down to grass, (4) hay or pasture, (5) summerfallow. 

off.

9. The squaw varieties are most useful for grain or hogging

10. For fodder or silage production the early flints give the best results. Recommended varieties are Dakota White, Gehu, Burleigh County Mixed and Quebec No. 28. tion.

11. Before planting, the seed should be tested for germina-

12. Averaging the results of an eight year test at Saskatoon, the largest returns were produced by corn planted during the last 10 days of May at the rate of 20 pounds of seed per acre. factory.

13. Rows $31 / 2$ feet apart have been found to be most satis-

14. When hill planted only 8 to 12 pounds of seed per acre are required. trol.

15. Hill planting or checking corn is the best for weed con-

16. Corn requires cultivations to be frequent, shallow and continued late.

17. The crop should be left as long as possible and yet harvested before frost. If frosted it should be cut immediately. The grain binder may be used successfull,v but the corn harvester is most satisfactory.

18. Corn may be stored in long rows near the buildings, in stacks or lofts, with alternate layers of straw, or in a silo.

19. No costly equipment is necessary to start growing corn, but the planter, cultivator and binder are very desirable because of the time which can be saved by their use.

Rrgina: Printed by J. W. Rril, King's Printer. 
a 


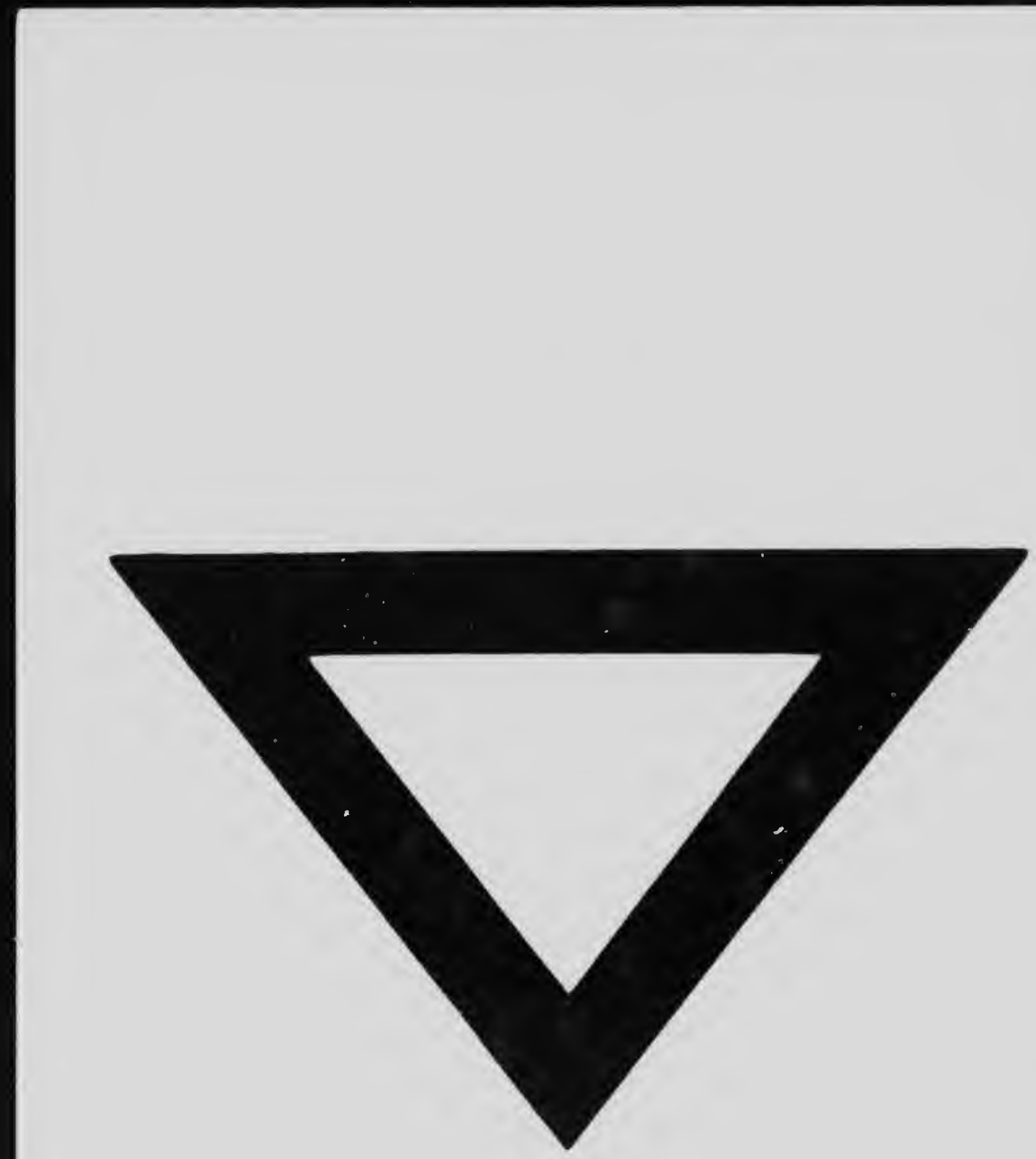

7

, 